\title{
Potential for Thermal Enhancement by Quercetin Mediated Mechanisms Targeting p53 Antagonists in Human Melanoma Cells
}

\author{
T. Thangasamy \\ University of Arizona \\ K. Limesand \\ University of Arizona \\ D. B. Leeper
}

Thomas Jefferson University and Hospitals

R. Burd

University of Arizona

Follow this and additional works at: https://jdc.jefferson.edu/bodinejournal

Part of the Oncology Commons

Let us know how access to this document benefits you

\section{Recommended Citation}

Thangasamy, T.; Limesand, K.; Leeper, D. B.; and Burd, R. (2010) "Potential for Thermal Enhancement by Quercetin Mediated Mechanisms Targeting p53 Antagonists in Human Melanoma Cells," Bodine Journal: Vol. 3 : Iss. 1 , Article 5.

DOI: https://doi.org/10.29046/TBJ.003.1.004

Available at: https://jdc.jefferson.edu/bodinejournal/vol3/iss1/5

This Article is brought to you for free and open access by the Jefferson Digital Commons. The Jefferson Digital Commons is a service of Thomas Jefferson University's Center for Teaching and Learning (CTL). The Commons is a showcase for Jefferson books and journals, peer-reviewed scholarly publications, unique historical collections from the University archives, and teaching tools. The Jefferson Digital Commons allows researchers and interested readers anywhere in the world to learn about and keep up to date with Jefferson scholarship. This article has been accepted for inclusion in Bodine Journal by an authorized administrator of the Jefferson Digital Commons. For more information, please contact: JeffersonDigitalCommons@jefferson.edu. 


\section{Potential for Thermal Enhancement by Quercetin Mediated Mechanisms Targeting p53 Antagonists in Human Melanoma Cells}

Thangasamy, T., ${ }^{1}$ Limesand, K., ${ }^{1}$ Leeper, D.B., ${ }^{2}$ Burd, R. ${ }^{1}$

${ }^{1}$ Department of Nutritional Sciences, University of Arizona, Tucson, AZ

2Department of Radiation Oncology, Thomas Jefferson University and Hospitals, Philadelphia, PA

\section{Introduction}

Recently Temozolomide (TMZ) has become the more commonly used analog of DTIC-related oral agents. Although the response rates achieved by TMZ alone are less than satisfactory, there is great interest in identifying compounds that could be used in combination therapy. We have previously demonstrated that the bioflavonoid quercetin (Qct) promotes a p53-mediated response in melanoma and sensitizes melanoma to DTIC. Here we demonstrate that Qct also sensitizes cells to TMZ by a mechanism that involves the modulation of a truncated p53 family member, $\Delta \mathrm{Np} 73$.

\section{Methods}

DB-1 (p53 wild type), and SK Mel 28 (p53 mutant) human melanoma cell lines were treated with TMZ $(400 \mu \mathrm{M})$ for $48 \mathrm{hr}$ followed by exposure to Qct $(75 \mu \mathrm{M})$ for $24 \mathrm{hr}$. Cell death was determined by Annexin V-FITC staining, and immunocytochemical analysis was carried out to determine protein translocation.

\section{Results}

After treatment with TMZ, DB-1 cells demonstrated increased phosphorylation of mutated ATM and p53. However, the cells were resistant to TMZ-induced apoptosis and the resistance was associated with an increase in nuclear localization of $\Delta \mathrm{Np} 73$. Qct treatment in combination with TMZ abolished drug insensitivity and caused a more than additive induction of apoptosis compared to either treatment alone. Treatment with Qct caused redistribution of $\Delta \mathrm{Np} 73$ into both the cytoplasm and nucleus, which has been associated with increased p53 transcriptional activity. Knockdown of $\Delta \mathrm{Np} 73$ restored PARP cleavage in the TMZ treated cells, confirming its antiapoptotic role. The response to treatment was predominantly p53 mediated, as the p53 mutant SK Mel 28 cells did not show significant enhancement of apoptosis.

\section{Conclusion}

This study demonstrates that Qct can sensitize cells to TMZ and that the mechanisms of sensitization involve modulation of p53 family members. These results strongly suggest combination with hyperthermia in this treatment scheme. The inhibition of heatinduced p53/HSF1 by inhibiting p53 would diminish HSP70 levels thereby enhancing the heat sensitization of DNA-damage induced cell death [Sharma A, et al. Cancer Sci. 2010 Jan 28. Epub ahead of print].

Supported in part by NIH P01 CA36690 and K22 DE 16096. 